\title{
Pathways of diffusion of some plants and animals between Asia and the Mediterranean region
}

Voies de diffusion de quelques plantes et animaux entre l'Asie et la région méditerranéenne

\section{Françoise Aubaile}

\section{CpenEdition}

\section{Journals}

Electronic version

URL: http://journals.openedition.org/ethnoecologie/714

DOI: $10.4000 /$ ethnoecologie.714

ISSN: 2267-2419

\section{Publisher}

Laboratoire Eco-anthropologie et Ethnobiologie

\section{Electronic reference}

Françoise Aubaile, «Pathways of diffusion of some plants and animals between Asia and the Mediterranean region », Revue d'ethnoécologie [Online], 1 | 2012, Online since 30 June 2012, connection on 19 April 2019. URL : http://journals.openedition.org/ethnoecologie/714 ; DOI : 10.4000/ ethnoecologie.714

This text was automatically generated on 19 April 2019

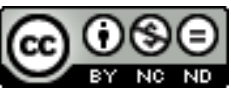

Revue d'ethnoécologie est mis à disposition selon les termes de la licence Creative Commons Attribution - Pas d'Utilisation Commerciale - Pas de Modification 4.0 International. 


\section{Pathways of diffusion of some plants and animals between Asia and the Mediterranean region}

Voies de diffusion de quelques plantes et animaux entre l'Asie et la région méditerranéenne

Françoise Aubaile

\section{Introduction}

1 Knowledge of the centres of origin of plants and animals has increasingly improved. However, it is much harder to identify the way through which plants and animals were distributed, by what roads and what means they arrived at one place or another, who brought them and who diffused them and why. Even for the most important and prestigious ones, many uncertainties persist. We cannot claim to resolve them, but we will present what is known to date.

2 In the old Eurasian world, three major centres of origin and domestication are known : in the Middle East, the area called the Fertile Crescent; in China, the Yang Tse Kiang valley; and in Pakistan, the Indus Valley. From those three centres, plants and animals were diffused to the west and to the east, as we shall see.

3 However, most plants and animals, which went from one cultural area to another, are related to population movements and thus to human history. Moreover, some are the result of a conscious, deliberate action of humans. We can note the example of Christopher Columbus, who discovered the marvellous corn in the islands of America, a staple food of the Caribbean; he brought it back in his second journey, in 1493. 


\section{The roads}

4 Seidenstrassen - "silk roads" - is a term created in 1877 by geologist and traveller Ferdinand Paul Wilhelm von Richthofen (1833-1905)1. Fundamentally wrongly-appointed, those roads were of huge economic importance, and were indeed used for thousands of years before the invention of silk. According to Juniper and Mabberley (2006: 120), they were almost certainly animal migration routes linking the springs and pastures, long before the emergence of Man and the establishment of agriculture, around $11000 \mathrm{BC}$ (Juniper \& Mabberley $2006: 120$ ).

5 They are also the areas of two main domestications: that of horses and that of camels around 3000 BC (Masson 1964; Juniper \& Mabberley 2006: 78). As a result, we may question the relationship between the domestication of camel, a pack and draft animal, and long-haul trade on these roads of Central Asia. It is very tempting to consider that the domestication of camel boosted and facilitated, and even created and launched long-haul trade between China and the Mediterranean. All the more so as we know of the existence of many oases probably linked to those roads since the Bronze Age.

6 One feature that certainly helped in the self-diffusion of many plants and animals was the land continuum from the Yang Tse Kiang valley to West Asia, through areas less desert than they are nowadays.

7 There were three main itineraries. The land roads were the most ancient in Central Asia : the northern one, the oldest, by which carp and cock probably naturally migrated ; and the more southern routes, which constituted the diffusion roads for flowers, fruit-trees and animals, and since the Han dynasty (206 BC-AD 220), for silk, historically linking the China of the Han, then of the Tang (618-907), to the Imperial Rome and the main centres of the west (Juniper \& Mabberley $2006: 120$ ).

In the past century, archaeology has brought to life those immense areas of Central Asia by discovering many settlements of the Bronze Age, mainly oases, such as Anau - one of the oldest oases going back nearly seven thousand years to at least $4500 \mathrm{BC}$, in the Kara Kum desert of Turkmenistan and Uzbekistan on the Iran and Afghanistan borders (Hiebert-Howe 2001). Those that were along the Amu Darya (Oxus) tributaries, in Bactria (northern Afghanistan and southern Uzbekistan) and in Margiana (the Murghab delta of eastern Turkmenistan), generally date back to the fourth millennium BC; they all had similar features and generally formed peaceful economic and cultural complexes, outposts attracting northern nomads, leading them to settle down, and therefore importing elements of nomadic culture into sedentary societies. This is reflected in town planning, architecture, pottery and jewellery crafts (Hiebert 1994: 91). These places all constituted intermediate stops on these roads since very ancient times : Namazga, Kelleli, Kalta Minor, Gonur Tepe, Togolok in Margiana - the remains of which go back to $c a .4000$ $\mathrm{BC}$ to $c a .1700 \mathrm{BC}$-, the vast Merv oasis - the remains of which go back to $2000 \mathrm{BC}-$, as well as the large complex oases of Niya in the Tarim Basin dating back to the late Bronze Age (Masson 1964 ; Hiebert 1994 ; Rossi-Osmida 2002), and the oases of Xinjiang.

The third itinerary is the sea route : the most recent one dates back to the first century of our era. This Chinese maritime route was very active around the year 700; the Tang Annals mention Tiyu, which is Diu port on the southern coast of Gujarat, where Chinese boats that went to the Persian Gulf put into port (Deguignes in Yule $1984: 319$ ). However, this 
route was not as secure as the Central Asian ones. When the Arabs were in Canton in the eighth century, there were social fluctuations, changes in the political balance that led to the closure of sea roads and thus to reinforcing land roads ${ }^{2}$ (Boulnois $1986: 77$ ).

On these roads, animals strode, plants and precious products were transported, such as lapis lazuli, the mines of which were in Sar-e-Sang, in Badakhshan, province of Afghanistan, $250 \mathrm{~km}$ north-west of Kabul, and whose trade can be dated to $3000 \mathrm{BC}$ : it was found in the treasure of the queen Pu-abi in Ur, 2600 years BC, and decorated the mask of Tutankhamun (died 1327). Also, jade of Central Asia arrived in China very early. Techniques, ideas and religions were also conveyed on these roads.

\section{How did plants travel and how were they introduced?}

11 As regards plants, people carried seeds with them, but this only worked with cereals and shelled fruit - e.g. walnut, pistachio - and stone fruit - e.g. apricot, peach. For pip fruit such as apple and citrus, reproduction is very unpredictable; they had to take a young tree or grafts and could not go very far; therefore diffusion occurred step by step, and was linked to the acquisition of grafting techniques (this skill was known since ancient times in China and Mesopotamia). Bulb plants, like narcissus, were very easily transported. In addition, of course, plants were diffused with birds, rodents; and fabrics, clothes, animal furs, etc. held seeds.

The introduction may also have been done with tributes, the ambassador's gifts; a new plant or animal was offered to the emperor of China who had a garden, a park with all the animals and exotic and prestigious plants (Schafer 1968). This could have been the case of narcissus, which was greatly successful, as will be described hereinafter.

Journeys also highly contributed to introducing new plants: one of the most famous Chinese travels is that of Chang Ch'ien - who was ascribed many fruit introductions - in the early times of the Han, the Egyptian expedition of Ramses II (1298-1235) in Bactriana (Rolland 1968: 102), the travels of the Greek Skylax of Karyanda in 512 BC, and especially the expedition of Alexander, which lasted 8 years (331-323 BC) and to whom many introductions were attributed, and finally the Roman travels - a delegation docked in $\mathrm{AD}$ 166 in a port now known as Ha Tinh, in Central Vietnam (Pelliot 1921 : 141).

14 A battle may bring a wealth of consequences. This was the case of the battle of Talas (Fergana), in 751, when General Ziyad ibn Salih - leader of the Khurasan army of Abû Muslim - defeated the Chinese army, which was composed of his many compatriots living in this rich Fergana Valley. Following this disaster, the Chinese never again occupied this western country they had conquered since the second century AD (Miller 1969: 252). Ziyad took many people as prisoners; among them were Chinese silk-weavers and paperworkers. He transferred the first to Iraq and the others to Samarkand, a city that became a great paper-manufacturing centre throughout the Middle Ages before the techniques spread to Europe (Boulnois 1994 : 29-30; Hambis 1964 : 782-785). But what did they make paper with in Samarkand? In China, they could have used the bark of Broussonetia papyrifera - a Moraceae - with many other things. This Muslim victory put an end to the Chinese expansion beyond the Tien Shan Mountains.

15 Although we know the areas of origin of most plants and animals present in the Mediterranean -i.e. they are historically confirmed by texts and located by archaeological finds -, we cannot tell in what period they arrived and how they arrived in 
one site or another. Nowadays, genetics will connect isolated points provided by archaeology.

\section{Introductions in the Mediterranean before Greco- Roman times} domestication centres have been identified in South-East Asia and India. Besides the red jungle fowl Gallus gallus gallus, the major ancestor species, originated in South-East Asia, the grey jungle fowl, G. sonneratii, from the Indian continent, contributed also to the genetic make-up of the world domestic chicken (Tixier-Boichard et al. 2011). The red jungle fowl spread towards the north and established in several sites of the Yellow River by the sixth millennium BC (West \& Zhou 1988). Its diffusion in several dispersed sites of Europe is explained by a northern road through South Siberia and the Russian steppe. According to the study of West and Zhou (1988), in 4000 BC it was simultaneously in Iran, Ukraine, Romania and the island of Rhodes; in $2400 \mathrm{BC}$, it was in Turkey, Syria and the Argolid (Greece); and curiously in $1500 \mathrm{BC}$, it was in Southern Spain - Cerro Real and Cerro de la Virgen -, in the province of Granada (West \& Zhou 1988 : 218-521).

Its presence in Egypt may provide evidence for the far-reaching marine trade of the Egyptians : it appears in the fifteenth and fourteenth centuries $\mathrm{BC}$ in a picture of the tomb of Tutankhamun, $1350 \mathrm{BC}$ (Zeuner $1969: 445)$ ). Yet its distribution is irregular as it is based on archaeological finds and we ignore its means of arrival: though the bird is present in Crete, Laconia, the Argolid in the Bronze Age (3000-1230), Aristophanes wrote in The Birds, in $414 \mathrm{BC}:$ : the medic bird is a stranger, it has a crest, it looses its feathers " (Aristophane / Poyard 1875: 256, 289) - because it had also been borrowed from the Medes during the Medic wars $(600 \mathrm{BC})$. The strange bird appears on seventh century BC Corinthian terracotta and on Greek red- and black-figure potteries. It still amazed the 
poet Cratinus (mid-fifth century BC, according to Athenaeus), who called it « the Persian alarm ».

Can it be said that this bird was diffused with the same representations as those of its countries of origin? Among the Romans, it was an oracle bird both in flight, and when eaten as a meal. A hen was a good omen (auspicium ratum) when it appeared to come from the left (Cicero 44 BC; Freyburger \& Scheid 1992), just as a crow or an owl. Similarly, among the Chinese, burnt rooster bones were used for divination. Their sacrifice was an integral part of magic and such practices emerged in China long before the Qin. Roosterrelated divination practices stemmed from the belief that the birds were divine messengers. Chicken was frequently mentioned in Shang oracle bone writings and its bones are common finds in Anyang (Chang 1977 : 29-30).

\section{Horse Equus caballus L.}

Horse, for which we no longer possess wild specimens, originated in Central Asia. Around 5000 to $3000 \mathrm{BC}$, an important change in steppe ecodynamics occurred with a significant climatic change; at the same time, horses became more common in archaeological finds. Recent studies on horse bones and teeth found in north Kazakhstan clearly demonstrate the existence of animal domestication in Eneolithic Botai culture, with some bridled horses. Moreover, organic residue analyses reveal mare's milk processing and carcass products in ceramics, indicating a developed domestic horse-economy around $3500 \mathrm{BC}$ (Outram et al. 2009 (323) : 1332).

\section{Camel (Camelus bactrianus L.) and dromedary (Camelus dromedarius L.)}

Wild camel, Camelus ferus, was domesticated in Central Asia around 3000 BC. In SouthEastern Arabia, dromedary was present "from the early third millennium $\mathrm{BC}$ onwards... but the period of its domestication coincided with the dry spell from the second to the first millennium $\mathrm{BC}$ ". According to Uerpmann, the motivation for its domestication may have been the introduction of horse in Mesopotamia, the Levant and Egypt during the first half of the $2^{\text {nd }}$ millennium. The use of horse in warfare definitively increased the pressure on nomadic people of Northern Arabia (Uerpmann et al. 2002:237, 249)3. It is thought that dromedary entered into Egypt between 2600 and 1400 BC (Saber $1998: 208$ ) and into North Africa around the Christian era ${ }^{4}$. Both animals certainly could be used in trade caravans, the first in Central Asia, the second between the Persian Gulf and the shores of the Mediterranean.

The first mention of dromedary as a domestic animal in historical sources goes back to $1100 \mathrm{BC}$, when the northern tribes of Arabia, mounted on dromedaries, attacked the Mediterranean coasts (Judges 6; Uerpmann 2002 : 251; Albright 1949).

\section{Regarding plants}

\section{Rose}

Rose originated in Central Asia. It arrived in China very early but was also formerly found in the Mediterranean, where only dog rose - Rosa canina - was known. Rose, which is by far the flower of beauty and fragrance, has since always been carefully cultivated; it was therefore one of the first domesticated and diffused plant. In the Mediterranean, its 
names - in Greek, rodon, and in Arabic, ward - are related to and probably borrowed from an older common term, which is still unknown to us. Damascus rose, a very ancient variety, is a beautiful and very fragrant flower that was distilled when this technique was developed in Syria in the eighth century, to get the attar of roses.

\section{Sweet apple Malus pumila L.}

The growing of apple trees bearing edible fruits probably first occurred in Central or Western Asia, in very ancient times. Very early, it reached the Western Mediterranean through Asia Minor, Greece, Roman Italy (Aubaile-Sallenave \& Haudricourt 1995: 465-506). Two theories :

1) that of Vavilov (1887-1943) who supposed a Central Asian origin (Russian Turkestan, i.e. nowadays Turkmenistan, Uzbekistan, Kyrgyzstan, Tajikistan, Kazakhstan, West China, and Northeastern Afghanistan). In the Tien Shan Mountains, there are huge forests of Malus pumila, whose sweet apple fruit can be the size of a child's head'.

2) that which recognises the area with the greatest species diversity as Central and Southern China (Juniper \& Mabberly $2006:$ 47) (Fig. 1).

Figure 1. Map of the origins of the sweet apple

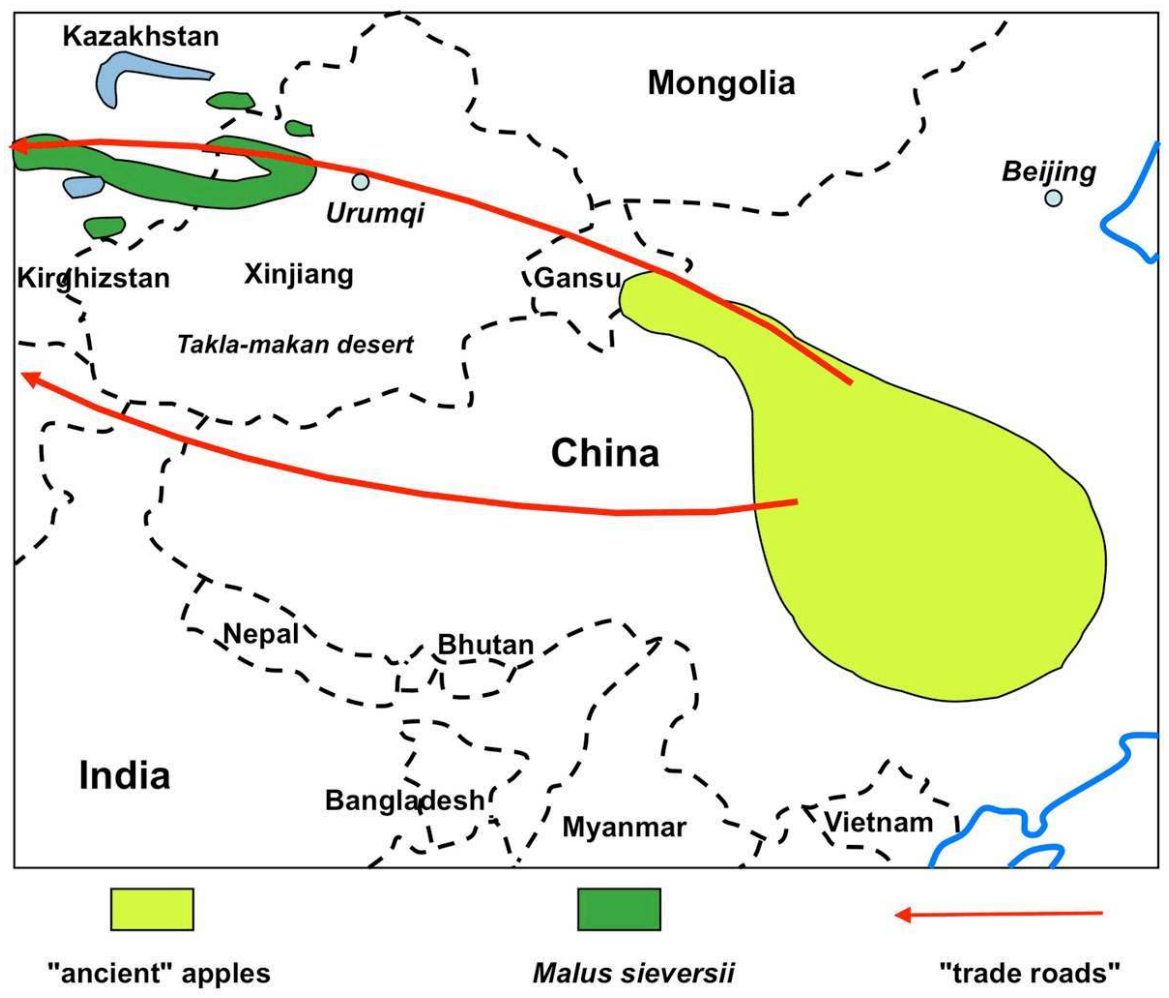

(AFTER HARRIS ET AL., $2002:$ 427)

Imported in Western Asia very early, it is mentioned in cuneiform writings around 1800 BC as being brought down the great Mesopotamian waterways (Juniper \& Mabberly 2006 : 90). It appears among the trees planted by Ramses II (around 1295-1186) in his gardens, in the Nile Delta. Its fruit filled 848 baskets offered by Ramses III to the priests of Thebes (Leclerc 1933: 107; Darby et al. $1977:$ 697-9). Nevertheless, these three examples are definitively not in favour of Malus pumila's origin, all the more dubious since the Egyptian 
term for the apple - $d p h$ - was related to that in Hebrew - tappuh - (related to Coptic, djepeh, and Arabic, tuffah) (Darby et al. $1977: 697-9$ ), and to date it is not clear whether the Hebrew term tappuh referred to the apple (Moldenke 1952 : 185-187).

The only apple native to the forests of temperate Europe is Malus silvestris Mill., a small and very acid fruit that gave an acid drink, pommata. Current cider apples are clones, foreign to Europe. Thus the improvement of the fruit occurred outside Europe, in Asia.

According to Theophrastus, the Greeks grew several varieties of apple (melea). Latin people knew 32 apple clones. In 800, the Capitulare De Villis issued by Charlemagne appointed five clones but suggested that there were more. At that time, people could drink pomacium, an acrid beverage. But sicere - cider - appeared in 780, in an Asturian document referring to an endowment for the foundation of the monastery of Santa Maria. At the end of the eleventh century, sidre was brought to the Auge Valley, in the province of Normandy, with new varieties of apple trees good for making cider ${ }^{6}$.

In Eastern Asia, apple species, like pear and chestnut species, are distinguished from West Asian ones due to their resistance to various diseases (Juniper \& Mabberley 2006). The oldest record of sweet apple in China dates to 400-300 BC (Juniper \& Mabberley 2006: 115).

Apple trees are clones, pure vegetative descendants whose vegetative propagation is achieved by grafting, which requires specialist skills ${ }^{7}$. Hence, in principle, the longevity of apple varieties can be very high. Texts of Latin agronomists show that perhaps we still cultivate varieties that were known to them, which emphasizes the almost infinite longevity of particularly vigorous varieties. However, these old varieties no longer show good productivity and health equivalent to those of younger varieties, as noted by the Spanish agronomist Guinea (Guinea Lopez 1957: 13). The lifespan of an apple tree is slightly less than half a century to a century ${ }^{8}$.

\section{Pistachio Pistacia vera L.}

7 Pistachio, from Central Asia, seems to be widely diffused, from Northern Syria to Central Asia : there are wild pistachio forests in Kyrgyzstan, slightly below walnut forests, close to Osh. It is present in Babylon (Campbell Thompson 1949 : 252-253). The Arabic term fustuk was borrowed from Persian, which provides evidence for its Central Asian origin.

\section{Black mulberry Morus nigra}

Black mulberry, is a medium-high tree with black fruit that originated in Central Asia. It arrived in Persian Transoxiana very early and was quickly introduced in Babylon where musukânu was highly cultivated for the excellence of its wood in carpentry and for its fruit (Campbell Thompson 1949 : 316-317).

39 It was known in Greece fairly late, unknown to Theophrastus (370-285 BC), but Dioscorides (AD 40-90) knew it and named it moron. It was grown by the Latins who named it môrus: Ovid, Columella, Pliny called it sativa mora (Ovide Metamorphoses $4: 90$, Columelle (livre $25: 1$ ), Pline (livre $24: 120$ ). It is mentioned in the Fayyum archives of the third century AD (Newton et al. 2005; Pline 24 : 120; André 1985).

It cannot be related to the cultivation of silkworm cocoons, as mentioned by Yeh-lu Ch'u Ts'ai who accompanied Genghis Khan on his expedition to Persia in 1219-1224 (Bretschneider $18881: 21$ ). 


\section{Walnut Juglans regia} paleo-Iranian area (Haudricourt \& Hédin $1943:$ 127; Purseglove 1972 : 41, 53) ${ }^{11}$. They all show very ancient domestication and were diffused in India and the Middle East very early. Garlic was known in predynastic Egypt, long before 3000 BC. Onion was a popular food in Ancient Egypt, and was eaten by pyramid builders since the first dynasties in $3200-2780 \mathrm{BC}^{12}$. It was diffused in Europe by the Greeks and Romans. Both were diffused and cultivated in China, and garlic seemed to be valued in Chou times (1200 BC - 221 BC), but it is difficult to be more precise (Chang $1977: 28$ ). The product early became essential to Chinese cuisine and Chinese garlic is nowadays an important export product.

\section{Coming from tropical SouthEast Asia}

\section{Plants}

\section{Pomegranate, Punica granatum L.}

Originated in tropical Asia. It was grown in the hanging gardens of Babylon, and was present in Egypt in the twelfth dynasty around 1786 BC (Purseglove 1968; Darby et al. : 698). It is mentioned in many passages of the Bible, in the text of the Exodus (28, 33-34, 39, 24-26), with the word rimmôn that the Greeks translated as roa (Theophrastus 4.13. 2), roia or kodon, which mean "bell". It was grown in the garden of Alcinous, as mentioned by Homer in the Odyssey. Many beliefs are linked to pomegranate, generally referring to femininity and fertility. Aphrodite, goddess of love and beauty, prepared love potions therewith. According to Greek mythology, she was the one who planted the first pomegranate. Pluto or Hades, god of hell, offered a pomegranate to the beautiful Persephone to seduce her.

From Palestine, the Phoenicians brought it to Carthage, a city they founded in $814 \mathrm{BC}$. The Romans knew the fruit there and brought it to Rome, hence its Latin then scientific name Punica. 

Thailand, Southwest China and North Vietnam. The earliest archaeological finds come from the site of Hemulu in the province of Zhejiang, in the Yangzi Delta, 5000 BC, and the sheer volume of rice shows that it was a real food supply to the villagers. There also were two early sites in North Thailand, prior to 4500 BC (Bray 1986: 8-10). In the Yang Tse Kiang valley, archaeological excavations show a collection of wild rice dated to $13000 \mathrm{BP}$. After a break, perhaps explained by a drought, the technique involving rice grown in layers emerged in 9000 BP. From there, rice reached India from that period. According to Zohary and Hopf, O. sativa was introduced into the Middle East in Hellenistic times, between 400 and $300 \mathrm{BC}$, and was recorded in Babylon and lower Syria around $285 \mathrm{BC}$. They report that a large sample of rice grains was recovered from a grave at Susa in Iran (dated to the first century AD) (Zohary \& Hopf 2000 : 91). It was familiar to both Greek and Roman writers. In the time of Pliny, rice was grown in India (Pline (18) : 71). Under the Sassanid dynasty, it was found in the well-irrigated regions of Southern Iraq (AubaileSallenave $1984: 62$ ). The Arabs brought the plant to Spain and to Sicily. Its cultivation began in the Valencia Vega around the tenth century, just as in Sicily. The Aramaic term ourouzza then led to the terms ruz in Arabic and oryza in Greek.

From Spain, it was introduced in Lombardy in the wake of the armies of Charles V in 1475, then in the south of France.

\section{Pepper, Piper nigrum}

Pepper is a vine native to the Malabar Coast in Southwest India. It is probably the most ancient spice that was carried from India to the Mediterranean, but in the Antiquity, it was ignored where it came from. Theophrastus (20.9. 1-2) described the fresh red grain according to the accounts of Alexander's soldiers. It is interesting to note that the Romans knew Piper longum originating from the foot of the Himalayas (Purseglove 1968: 436).

\section{Introductions in the Mediterranean in Greco-Roman Times}

51 Contacts were intensified mainly with the campaigns of Alexander of Macedon (356 - 323 $\mathrm{BC}$ ), whose soldiers were ascribed the introduction of peacock, peach, citron, etc. The Roman conquests in the Middle East then gave way to long stability that favoured longhaul trade by land and partly by sea: Roman coins were found in the Cham region, Central Vietnam ${ }^{13}$.

Hence, since the Greek and Roman periods, a wide variety of new fruits are grown in the Mediterranean, originating from the Far East, Central and tropical Asia, and new valuable animals are also bred for food and prestige.

Revue d'ethnoécologie, 1 | 2012 


\section{Animals}

\section{Carp, Cyprinus carpio}

Originating from Central Asia, was the first domesticated fish. Its natural migration followed the rivers to China on the one hand and to the Euphrates and Danube basins on the other hand (Zeuner 1969: 480). Carp breeding in China goes back long before the Christian era (Schafer 1967: 102). Introduced by the Romans approximately 2000 years ago from central Europe where they had their important colony of Pannonia (Balon 2004 : 7-8), carp was then widely diffused in the Middle Ages by the monks, who bred it in their piscina. It probably gave rise to the first fish farms in Europe.

Its hardiness - it is omnivorous and sometimes carnivorous - favoured its moving and acclimatisation. It is found throughout Western Europe except in cold regions. It particularly appreciates water with temperatures between 27 and $32^{\circ} \mathrm{C}$.

\section{Pheasant, Chrysolophus pictus}

Pheasant is native to the jungles of mountainous Central China. It lives in wild forests and mountains with severe weather. Its name derives from the Latin term phasianus, the Phasis River in Colchis, which may indicate the northern route from China. In China, it was a common food since the earliest times (Schafer $1977: 102$ ).

Few accounts exist as regards pheasant, though peacocks and pheasants were admired by eccentric rich Romans : they were the subject of many stories. According to Suetonius, Vitellius' brother offered him a famous banquet : they served two thousand of the most prestigious fishes and seven thousand birds. He himself even surpassed that sumptuousness by inaugurating a dish that he liked to define as «the shield of Minerva, protective of the city ", due to its extraordinary dimensions. This dish was a mix of scarus livers ${ }^{14}$, pheasant and peacock brains, flamingo tongues, soft roe of moray eel, which were all precious products that his ship captains and their trireme crews had sought from the country of Parthia until the closing of Gades (Suétone [1 ${ }^{\text {st }}$ AD] $1967: 435$ ). It was first imported into England and then into other European countries.

\section{Stone fruit : peach, apricot}

\section{Peach, Prunus persica L.}

Peach is a fruit of the Silk Road. It is native to China and was domesticated there between 3300 and $2500 \mathrm{BC}$. There are traces of its presence in the wild in South China around 500 $\mathrm{BC}$. However, it is noteworthy to know that, twice in the seventh century, the Tang court received golden peaches from Samarkand, "as large as goose eggs, and their colour like gold" ; they arrived in perfect condition though they crossed the Gobi Desert to Ch'angan, probably packed in snow as was the case of grape and watermelon (Schafer 1963:1, 117).

Unknown to Alexander (Theophrastus, $322 \mathrm{BC}$, does not mention it), it was probably introduced in Persia around the second or first century $\mathrm{BC}$, hence its name persica. It then arrived in Arabia, Mesopotamia, and Egypt, where peach was the fruit of Harpocrates, god 
of silence. It was found in excavations dating back to the Roman times in Egypt (Darby et al. 1977 : 698; Bois 1928 : 181).

Pliny claimed that peaches had recently been introduced from Persia and that the transplantation of peach trees on the island of Rhodes had failed, therefore the trees had been sent to Italy. Four varieties were grown in Rome and the fruits were sold at a high price. A fresco in Herculaneum shows peaches next to a water pitcher. One of them is bitten into and reveals its red and rippled stone (Pline $15: 44-45,12,14,13: 60,17: 151$ ). According to Columella ( $\left[3^{\text {rd }} C\right.$. $] 1844$ ), the fruit in Gaul were bigger but this luxury crop almost disappeared from Europe with the Barbarian Invasions (Bourdeau 1893: 54), and reappeared with the Crusades (Bois $1928: 183$ ).

\section{Apricot, Prunus armeniaca}

Apricot to some scholars, is native to Central Asia (Janick 2001 : 511) and, to others, native to China ${ }^{15}$. Nevertheless, it was diffused through Central Asia on the silk roads.

61 The history of apricot goes back to 2200 years BC in China with its mythical discovery by the emperor Yu (2205 - 2198 BC) (Leclerc 1933 : 74-75). The first historical references were recorded in $658 \mathrm{BC}$. Orchards were described in $406-250 \mathrm{BC}$. The grafting of apricots appeared in $600 \mathrm{BC}$ with varieties clearly defined since that time. The importance of apricot in China was also related to toponymy: about eleven names of Chinese cities include the word xing, which means apricot.

In Central Asia, apricot seems to have been naturalised in Sogdiana (in Samarkand and Armenia), but the lack of wild apricots there seems to indicate that Armenia was simply the route by which apricots arrived to the Mediterranean and Central Europe.

It is said that Alexander introduced apricot in Greece and Epirus, but this introduction seems to have been very slow as the fruit was unknown there by Theophrastus, and in Italy by Cato and Varro. References to apricot by Dioscorides, Columella and Pliny indicate its arrival in Greece and Rome in the first century BC.

Our term apricot derives from the Greco-Arabic term al-praecox, which means "early fruit" and gave the Spanish term albaricoque. The former name apricock subsisted in English until the seventeenth century. The fruit's richness in sugar makes it suitable for drying, as can be seen in the Middle East. In China, it is preserved by salting and smoking.

\section{Root Crops}

\section{Carrot, Daucus carota}

Originated in the Hindu Kush-Himalayan region (Kashmir-Afghanistan) but the centre of diversity for the western carrot is the Anatolian region in Asia Minor (Turkey) (Janick 2001). Theophrastus describes two varieties of daukon, both of which are medicines : one with a black root in Patrai, in Achaia (IX, xv, 8 ; IX, xx, 2) and one which is a saffroncoloured plant (IX, $\mathrm{xv}, 5)$ with no more precision. Nowadays, dark violet-coloured varieties are known. 


\section{Originating from tropical SouthEast Asia}

\section{Animals}

\section{Buffalo, Bubalus bubalis}

Buffalo is a multipurpose animal (draft, dairy and meat), native to India. Its domestication occurred among the Yangtze, Indus, and Tigris-Euphrates civilisations, in the third millennium BC (Cockrill 1981; Nachtsheim \& Stenfel 1977; Kierstein et al. 2004 : 309).

Buffalo seems to have been established in Anatolia, a favourable land with many swamps, in the second millennium $\mathrm{BC}$, since it appears on Cappadocian zoomorphic terracotta (Dupré 1993: 144; Casabonne 2003). Its presence in Transcaucasia is evidenced by archaeological finds of skulls and other bones dated to the first millennium BC (Verdiev \& Turabov $1989: 375)^{16}$.

In $263 \mathrm{BC}$, the Goths and Gauls invaded Asia Minor, destroying most of the Greek cities. The Gauls settled in Anatolia (Galatia). The Celtic populations there probably knew buffalo with which they then conquered Southern Europe on their carts drawn by buffaloes.

Although Aristotle and Aelian described buffalo as an ox from Arachosia (Media), it was unknown in Greece and Italy. It was first brought to Italy by Alboin, king of the Lombards, when, in 568 or 569, he subdued Northern Italy, coming from Pannonia with many tribes (Cantù 1860 IV : 9). In 594, Agilulf became the fourth king of the Lombards in Italy and, through his conquests, he diffused buffaloes in the marshes of central Italy ${ }^{17}$.

\section{Peacock}

Peacock was probably brought by Alexander, who found it so beautiful he banned its killing. In all places, it is a prestigious bird. In Greece, a friend of Pericles - Pyrilampes kept curious birds, especially peacocks, to offer them to Pericles' beloved ${ }^{18}$.

Peacock is very often represented on Roman mosaics of North Africa and the Middle East. In the famous Feast of Trimalchio witnessed by Nero, a hen imitation was placed in a laying-position, with its wings spread out, under which peacock eggs were found. Varro and Pliny (X 20) claimed that they kept 100 peacocks in Rome, which produced nearly 3,000 gold franks a year.

\section{Plants}

\section{Taro, Colocasia antiquorum}

Originating from Oceania, was so-called in Latin because it was first found in Egypt where it was grown in flooded areas, according to its biology. It arrived there shortly before the Christian era. This fat tuber is certainly easy to transport by boat. It could have come to Egypt from India, but by what path? (Haudricourt \& Hédin 1943 : 141; Plucknett 1976: 10-11). It did not arrive by the marshes of Southern Iraq and there is no indication in the vocabulary. The arguments put forward by different scholars, whether ancient or modern, are unsatisfactory ${ }^{19}$. 


\section{Citron, Citrus medica L.} arrived in the Mediterranean much later, nearly a millennium afterwards. According to Haudricourt, India seems to be the most ancient centre for citrus fruits (Haudricourt \& Hédin 1943 : 144).

Citron was the only citrus known in the Antique Middle East, and was introduced in Greece around $300 \mathrm{BC}$ by the soldiers of Alexander. Theophrastus named it « apple of the Medians » (22; IV 4).

Etroj plays an important role in the ritual of the Jewish festival of Sukkot, or Booths, together with palm lulav, myrtle leaves hadassim and willow leaves - the four species that people should bless. This role explains its fast diffusion in the Western Mediterranean along with the Jewish diaspora after the destruction of the temple in AD 70. Medica is acknowledged by Isidore of Seville in the $6^{\text {th }}$ century (Orig., 17, 7, 8). The Romans named it «malum citreum », later shortened to " citreum ». The name was finally set, in the $17^{\text {th }}$ century, by Swedish botanist Linnaeus who chose « citrus » as the name for this genus.

\section{Cucumber, Cucumis sativus L.}

Cuncumber is a cultigene from tropical India according to Haudricourt (1943), and from the Sino-Himalayan area according to Purseglove (1968) then Mabberley (1997).

Just as gourds, cucumber arrived in the Mediterranean regions very early. However, scholars nowadays are doubtful of its presence in Egypt and the Levant before the GrecoRoman period (Zohary et al. $2000: 183$ ). Cucumber was well-known by the Greeks in the fourth century BC; they called it sikyos (Theophrastus 1968 (IX) : 10) and the Romans called it pepo and cucumis. They were crazy about it, just as the Emperor Tiberius. In the Mediterranean, many cultivars were created, yielding fruits of different sizes and shapes. It was later known in China, in Tang times, arriving from East India (Schafer 1977 : 94).

\section{Introductions from the Mediterranean to Central Asia and the Far East}

71 It is also during this period of intensive movements in Central Asia that plants and animals arrived in the Far East coming from the Mediterranean : grape vine, narcissus, garden pea, henna, donkey, mule...

\section{Grape, Vitis vinifera}

Originated in the Near East and was domesticated in the Mediterranean; it first spread around the Mediterranean then worldwide. It is divided into two subspecies : sylvestris of Southern and Central Europe, Northwest Africa, Western Turkey, and Israel; and caucasia found in Bessarabia, Southern Russia, Armenia, Caucasia, Anatolia, Iran, Turkestan, and Kashmir (Janick 2001).

Hence, it was grown very early in the oases of Central Asia, in Bronze Age times: the oases of Niya in the Tarim Basin of the late Bronze Age had vineyards (Stein 1916: 115), Gonur Tepe populations in Turkmenistan (2200-1750 BC) grew it together with barley ( Hordeum vulgare subsp. Hexatistichum), wheat (Triticum aestivum) and pulse, lentils, 
chickpeas, grass peas and peas. Grapes seemed to be well-adapted in the oasis environment (Moore et al. $1994: 421)^{20}$.

In China, grain wine existed since the Shang dynasty $\left(c a .16^{\text {th }}-c a .11^{\text {th }}\right.$ century BC) and was widespread. It is acknowledged that the first wine grapes produced in China were made with Vitis vinifera, and that grape vine was introduced in China from Central Asia in the second century BC (McGovern et al. 2004: 17596). In Tang times, table grape was cultivated in Shansi but grapes were also imported from Kocho in Central Asia, in many forms such as wine, syrup, dried, "crinkled" and "parched" (Schafer 1977: 95). It is interesting to note that, according to the merchant Suleyman in the ninth century; the Chinese (of Southeast China) ignored grape wine and only drank rice wine (Reinaud 1845 (2) : 22).

\section{Alfalfa, Medicago sativa L., and Persian clover, Trifolium resupinatum}

Both forage grasses native to Asia Minor, were first diffused in Central Asia, concomitantly with the horse. They were known in China in Han times (Ronan 1978 : 39-40 ; Boulnois [1963] 1986: 42, 45), when Central Asian populations started sending horses as a tribute to the emperor in exchange for products such as tea, silk, etc. (AubaileSallenave 2005). Both grasses entered Greece after the Medic wars at the beginning of the fifth century BC.

In the Middle East, the Arabs, being experts in the art of breeding horses, used alfalfa early to increase the nutritional value of food for their animals.

Alfalfa and Persian clover, after China, reached North Korea where winters are severe and where Persian clover is much appreciated due to its winter-spring throughout performance (Evans et al. 2004).

\section{Safflower, Carthamus tinctorius}

Safflower is native to the Eastern Mediterranean and is an oleaginous dye plant. Its progress can be traced from Egypt in pharaonic times to the Pacific shores, which it only reached around the end of the first millennium AD. Unknown in early China, safflower was only introduced in the Empire in the third century AD, through Persia and Central Asia along the silk road, according to the Dunhuang manuscripts (Trombert 1997).

\section{Regarding animals}

\section{Donkey}

Donkey is a domesticated wild ass, which originated in the Nile valley. It was known in Egypt as a domesticated animal at least from protodynastic times, $3000 \mathrm{BC}$ (Beja Pereira et al. 2004 : 1781). It was quickly diffused in Western Asia : in the third millennium BC, it carried copper from Oman mines to the seaport (Uerpmann \& Uerpmann 2002 : 250). In the Bible, it appears in Gen. 12, 16 when the king of Egypt offered livestock to Abraham, including male and female donkeys; this perhaps meant the importation of donkeys from Egypt. The wide diffusion of the animal across Western Asia seems to coincide with the period in which camel became common and with the increasing aridity in the Near and Middle East (Zeuner 1969 : 375-7). 
It was brought to Central Asia no later than the middle of the $2^{\text {nd }}$ millennium $\mathrm{BC}$. This species was of considerable economic importance to the population of ancient oases in the Tejen and Murghab valleys in Turkmenistan (Istomin 1989 : 409).

It is difficult to date its introduction in the Far East. The only accounts of its former presence in China speak of both donkeys and mules, with reference to King Han Wu Ti's hunting park in $138 \mathrm{BC}$ (Schafer $1968: 329$ ).

\section{Mule}

Mule results from the crossing of a male donkey and a mare; although male mules are sterile, female mules successfully produce foals. The origin of mule is difficult to determine, but the practice of breeding these animals dates to at least 1000 years BC in Western Asia : mules were known in the Holy Land at the beginning of the time of King David (1015-975), replacing donkeys as the royal saddled animals. They were the king's mount (II Sam. $13: 29,18: 9$; I King $1: 33$ ).

The animal was well-known to Homer (eighth century BC) who recorded the arrival of mules from Henetia in Asia Minor, where their breeding was a local specialty. They were widely used as draft animals and in farming. In later days, they were bred in many areas of the Peloponnesus, particularly in Arcadia, and harness racing with mules, which started at Olympia in $500 \mathrm{BC}$, continued for more than 80 years. The Greek word for mule was hemionus, namely "half ass", and the word for a female donkey was muchlos, whence the Latin term mulus and the English term mule derived (Savory 1970).

It is quite definite that the Chinese knew the existence of mules during the Han dynasty as they were in the Han Wu Ti hunting park, but it is unknown when the Chinese could have produced them. In any case, in Tang times (618-907), they were saddle and load animals as are seen in the Dunhuang painting of cave 217 representing the Magic City (Tang Loaëc \& Colombel $1983: 30$ ).

\section{From the Middle Ages to the present}

During the long medieval period, until the Renaissance, two very broad and long-term movements explain much of the introduction and diffusion of fruits, cereals, pulses, not to mention techniques, ideas, religions, etc.

The first was the Muslim expansion, which originated in Medina in 622 and since brought into direct contact the Occident with the Middle East, Central Asia, the Indian Ocean, Southeast Asia and almost the Far East. Pilgrimages of Westerners and Easterners to Mecca had religious and commercial purposes.

The most important imports and agricultural innovations of food products are due to the Arabs, including rice and rice-growing techniques, sugar cane and sugar techniques, and banana. The latter two only passed through the Mediterranean before going to America, yet banana became the staple food for many populations. They also imported many different citruses, lemons and oranges, which gardeners multiplied to get varieties with differences in terms of flavour, time of maturity and preserving forms. They brought and acclimatised vegetables such as cauliflower, spinach, new fruit varieties including prune, peach, apple, and new flower varieties, 
Christian side, the seven crusades in the Middle East stretched over nearly two centuries, from 1096 to 1270, leading to extraordinary discoveries of products and livelihoods unknown to medieval Europe. Among many things, they brought sweet marjoram.

\section{White mulberry Morus alba L.}

This tall Chinese tree was diffused together with Bombyx that produces silk. In addition to feeding silkworms, it yields fleshy white fruit. There are still controversies about the introduction of the worm-breeding technique. Londonian archaeology reveals that raw silk was made in Syria at least in the fourth century AD (Juniper \& Mabberley $2006: 126)^{21}$

However, the battle of Talas (Fergana) in 751 was certainly crucial to the diffusion of silk techniques as was mentioned earlier - General Ziyad ibn Salih transferred silk-weavers to Iraq.

The production, and therefore mulberry-tree plantations, spread so quickly that Wu-kusun Chung Tuan, an envoy of the emperor of China to Persia in 1222, noted as many white mulberry trees "as we have in China" 22 . From the $13^{\text {th }}$ century, silk techniques were first introduced in Italy; from the late $13^{\text {th }}$ century, they were brought to Anduze, in Provence. In 1309, Pope Clement V established his residence in Avignon and had mulberry trees planted around the city (Clavairolle et al. $1993: 32-34$ ).

\section{Rhubarb, Rheum rhaponticum}

Rhubarb is a vivacious plant up to one metre in height. It is native to Central Asia, more precisely the north-western part of China and the eastern part of Tibet. It was known in China in Han times (206 BC-AD 9) (Laufer [1919] 1967 : 547-549). To European medieval scholars, the rhubarb root mystery was its origin. Marco Polo, at the end of the thirteenth century, reported it growing in a vague location in Tangutia and in Suzhou in the Kiangsu Province (Yule 1903 (1) : 217-18, (2) : 181). Though the Andalusian scholar Ibn Beitar, who wrote his Treatise on medicinal plants in the $14^{\text {th }}$ century, replicated the well-informed long article on rhubarb by Ibn Djami - a famous Cairene Jewish physician of the $12^{\text {th }}$ century (Leclerc 1971 (2) : 54-55) - there may be doubts about the presence and use of rhubarb, unless as a dry trade item. Rhubarb root was a medicinal product known in western countries for its diuretic and laxative properties.

From the $12^{\text {th }}$ century, rhubarb root was imported in large quantities from China via Russia, Asia Minor including India, according to Linschoten (1610: 177). Introduced in Europe around the $16^{\text {th }}$ century, it was only ca. 1830 and 1840 that the British and the Americans planted it and dared to use the petiole of this beautiful ornamental plant in their cookery (Foust 1996 : 30).

\section{Tea, Camelia sinensis}

Tea showed a complex diffusion ${ }^{23}$. It is native to North East India. In China, tea was known before the Christian era. It was cultivated in the south-western regions. The leaves then were eaten in soups. It is nevertheless proven to have been a drink in the third century $\mathrm{BC}$ and, in the fourth century $\mathrm{AD}$, it was described how to make a hot drink by boiling tea 
leaves ${ }^{24}$. This description was the first mention of tea in the Arabic texts of 851, Relation de la Chine et de l'Inde by the trader Suleyman, a text highlighting how well these Arabic traders knew the Chinese society. It precisely describes the infusion of sakh, its bitterness and the taxes imposed thereupon by the imperial government (Sauvaget $1948: 18$ ). However, this information had no effect in the Muslim world. Several centuries went by before tea was significantly mentioned in the Mediterranean world.

In fact, China for a long time traded its tea for the Central Asian horses of the Uighurs who had been introduced to tea in the eighth century in Ch'ang-an, the Tang court, and were very fond of it (Schafer $1963: 20$ ). Actually, this was also a way to buy peace from these warlike populations (Ohsson 1852 [1] : 5) since horses were essential to the warlike Tang, then Song, then Ming dynasties. In Ming times (1368-1644), they grew tea for the export market, in Sichuan and Shaanxi (Hanzhong-Fu) (Rossabi $1970: 144$ ).

The diffusion of tea was confined to the area known today as Chinese Turkestan during the $13^{\text {th }}, 14^{\text {th }}$ and $15^{\text {th }}$ centuries. In 1500 , the Uzbeks of Central Asia invaded Transoxiana, and were probably those who brought tea in Bokhara. They still traded it with China a century later to supply large Iranian cities such as Ispahan.

Though known by Persian traders, tea was only adopted by city dwellers in Persia and Kurdistan in the $17^{\text {th }}$ century, along with coffee and tobacco. Olearius gives us a pleasant vision of life in Ispahan: there were three kinds of taverns - tsai chattai chane where honest people drank tea and played chess, shire chane where noisy people drank wine and danced, and chawa chane where they drank coffee and smoked tobacco (Olearius 1728 [1]: 534-5).

At the end of the $17^{\text {th }}$ century, the Europeans - the Dutch then the English - first took over the sea tea-trade and its diffusion in western countries. In the first half of the $18^{\text {th }}$ century, tea appeared in the westernmost part of the Islamic world - in Morocco-, putting forward the many influences that affected these cultures. It quickly became the drink of the wealthiest classes. The English are those who imported tea - green tea - into Morocco and, with tea, they brought its name tay - the southern Chinese pronunciation for tea - before 1750 .

The Russian court had immediately adopted tea in 1638 when the Russian ambassador brought back 200 packs of chai, as a tribute given by khan Mongol Altin Khan to Tsar Michel Romanov (Dymock 1972 (I) : 177). In 1689, a peace treaty was concluded between the Chinese emperor and the tsar. Since then, the tea route began through Siberia (Burkill 1935 : 417). The Russians were those who brought the tea and samovar to Turkey at the end of the $19^{\text {th }}$ century. Shortly afterwards, they began to grow it on the shores of the Black Sea.

Actually, East Turkey knew tea in the $17^{\text {th }}$ century, but in the large Turkish Empire, people had been drinking coffee since the $16^{\text {th }}$ century. This was probably the major obstacle to the adoption of tea, a much weaker drink, and explains its very slow introduction. In Istanbul, it was still unknown at the end of the $19^{\text {th }}$ and even the beginning of the $20^{\text {th }}$ centuries. The same occurred in the provinces of the empires of Tunisia, Algeria, Libya, Egypt, the Near East, Arabia and Yemen.

\section{Basils (Ocimum sp.)}

Basils from India are small bushes, with different leaf sizes and strong varied aromas. They give a good example of the introduction of a plant with its representations. In India, tulâsi is devoted to Shiva. The plant, first known by the Persians, was then diffused by the 
Arabs in the Mediterranean, with the same knowledge : in Greece, basilikon is the plant of Christ ; in Portugal, a pot of basil is offered; in some parts of Spain, such as Aragon, brides carry a protective bouquet in their vest; in southern Italy and North Africa, it preserves from bad influences; rare are the regions where it was part of cookery, such as in Genoese pesto and Provençal pistou.

\section{Sweet marjoram, Majorana hortensis Moench}

It'is a perennial plant of Central Asia. The Crusaders carried these small bushes in their luggage, and introduced them with huge success. Evidence is provided in the miniatures of the famous book Taqwîm es-Siha by Ibn Butlân (Antioch-Baghdad, 1066), translated into Latin in the $13^{\text {th }}$ century (Tacuinum Sanitatis), leading to numerous copies - one of the most famous ones being Codex Vindobonensis in Vienna ${ }^{25}$.

This plant was always represented as a small shrub in a flowerpot (ms Vienne c. v 33, Casanatense, CLX) or in a box, isolated from the soil (ms Paris, c. 30), which denotes careful cultivation for this new plant, the hardiness of which was still ignored. It is a garden plant.

The plant is often mistaken for the wild species Origanum vulgare L., native to the Mediterranean and rich in phenol. Sweet marjoram has a less pungent flavour and aroma than oregano.

\section{Jasmine, Jasminum sp.}

86 A vine from tropical Asia and China. The Arabs borrowed it from the Persians with its name yâsmîn, itself borrowed from India. Jasmine, together with rose, is one of the two queens of flower perfumes. Today, it provides one of the main and most expensive perfumes. Among over 200 species, the most common jasmines used in perfumery are J. grandiflorum also called "Spanish jasmine", J. officinale, native to Iran, introduced in the south of France in 1597 and cultivated in Grasse, and J. odoratissimum. Other species are mostly grown in gardens as ornamental vines.

\section{Eggplant, Solanum melongena L.}

87 Eggplant is a fruit-vegetable native to tropical Asia. It was first domesticated in India, arrived early in Persia and from there was diffused westward with the Muslim expansion. The Persian term bademjan, borrowed from the pâli term vâtingana, was then passed on to Arabic and Turkish, which themselves supplied various terms to Central Europe. It is an important part of Middle Eastern and, to a greater extent, Mediterranean cuisine (Janick 2001).

\section{Spinach, Spinacia oleracea L.}

Of Central Asia (Persia, Turkestan, Afghanistan), spinacia was known by the Arabs in Persia, where they took its name ispânay, which became isfanaj in Arabic. Its broad leaves certainly made it successful. It is annual or biennial.

The Arabs introduced it in al-Andalus and Sicily in the $10^{\text {th }}-11^{\text {th }}$ centuries. It soon became 
known in Italy and the south of France at the beginning of the $12^{\text {th }}$ century. Later in the Renaissance, it was popularised by the Italian French Queen Catherine de Medici.

\section{Sugar cane Saccharum officinalis}

From Southeast Asia and Oceania, sugar cane was formerly cultivated in India where raw sugar was made, already in $500 \mathrm{BC}$. Therefore, while the Antiquity had imported sugar from India around the Christian era, it ignored the cultivation of cane. Dioscorides clearly described sugar : "it is a kind of honey called saccharon, which has the consistency of salt and creaks under the tooth as salt, it is good for the stomach"26.

Under the Sassanides of Persia, it was grown in Mesopotamia in the sixth century AD. In South China, S. sinense was already cultivated around 100 BC (Darby et al. 1977 : 426 sqq.)

The Arabs were those who first introduced it in Egypt in the eighth century, then in Sicily, al-Andalus and parts of North Africa in the tenth and eleventh centuries.

The variety, which was first diffused by the Persians and shortly after by the Arabs, came from India; it was the thin-stemmed hardy cane S. barberi. Later, S. sinense was introduced from South China. Both were then introduced in Cuba, the West Indies and Brazil by the Spanish and Portuguese.

Since the $18^{\text {th }}$ century, the Europeans introduced S. officinarum in Central America, a thick-stemmed cane from the South Pacific, together with other species such as $S$. robustrum, a wild cane from Southeast Asia (Janick 2001).

As a revolutionary plant, its cultivation requires great physical effort and has always generated slave labour and thus revolts : those of the Zanjs - population imported from East Africa - in Iraq in the tenth century (al-Tabarî 1992) and those of the West Indians, also from Africa, in the $18^{\text {th }}-19^{\text {th }}$ centuries, have the same origin.

\section{Bitter orange, Seville orange, Citrus aurantium L.}

Originally from South China, the sour variety of Canton orange was early domesticated in India, confirming its Sanskrit name nâgaranga. The Persians borrowed the fruit with its name, which became nâranj, both terms then passing on to the Arabs. The tree was present in al-Andalus in the tenth century. The bitter fruit can only be eaten cooked with honey or sugar - the English created orange marmalade in the $18^{\text {th }}$ century - but the flower has a superb perfume and was widely used when distillation became popular in the $18^{\text {th }}$ century. Almost every house in North Africa had and still has orange perfume, the homemade azahar, for sprinkling friends during feasts or flavouring the many tiny cakes.

\section{Lemon, Citrus limonium L.}

91 From East India and South China; it arrived in the Mediterranean in several steps, as was described for citron and Seville orange. However, its features facilitated its diffusion : the fruit keeps well thanks to its thicker skin; the seeds hold their germination power for a long time; the plant is easily grafted and many varieties were known from the start (Photos 1 and 2).

The Arabs knew it in Persia, and had borrowed its Persian name lîmûn. It was hugely and durably successful due to its abundant, sweet and acid juice; it is ideal for making soft drinks such as lemonade and is used in cookery. It arrived later than orange and was 
grown in al-Andalus in the middle of the eleventh century : al-Tignari is one of the first to mention the cultivation of lîmûn with citron utruj and bitter orange nâranj (al-Tignarî $2006: 85)$.

Photo 1. A shadek tree in a garden of Javouhey, French Guyana

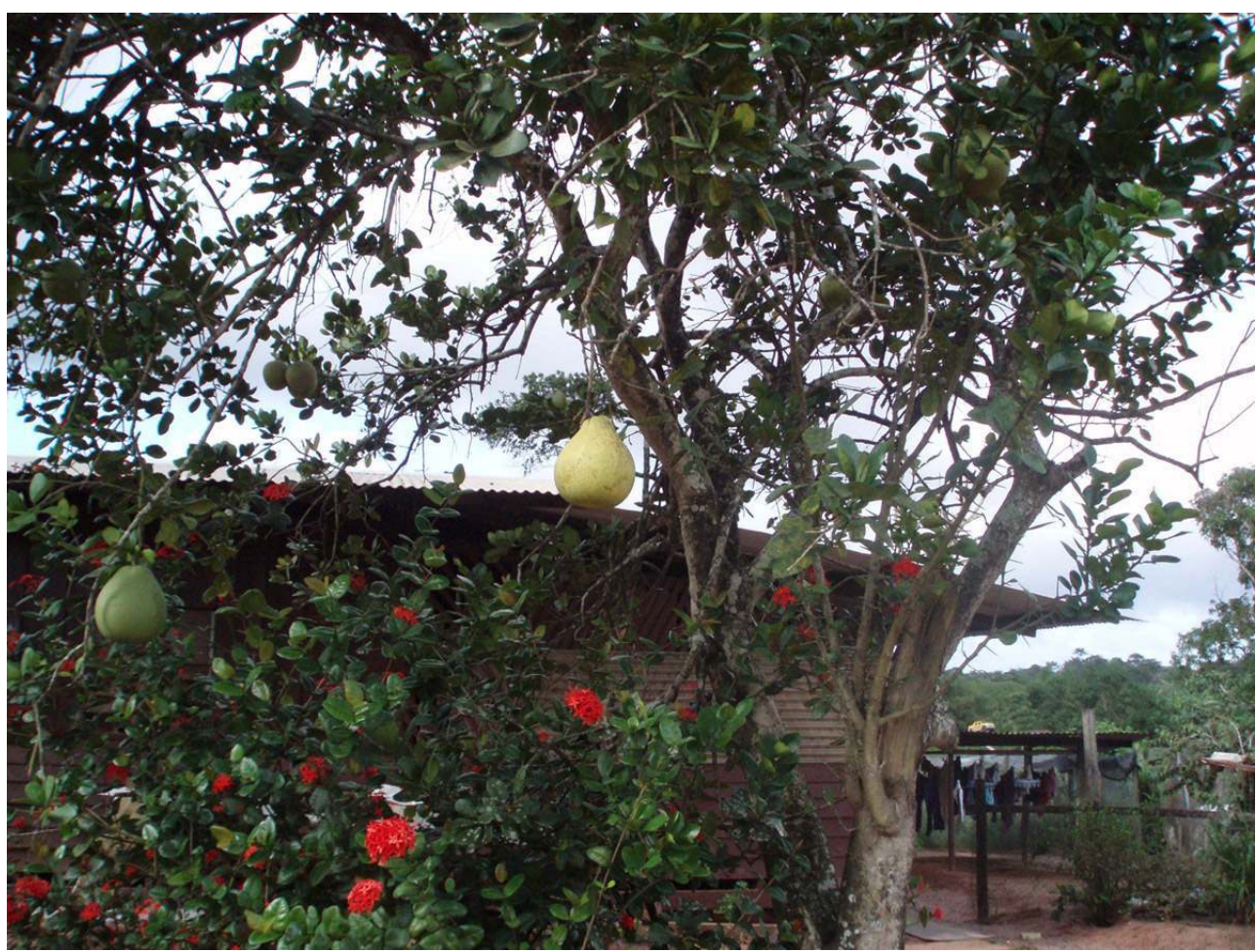

CLICHÉ F. AUBAILE, 2008

Of the three known citrus species, lemon was the one gardeners thought that most varied, unlike bitter orange which stayed nearly even until today. Yet, only that orange could acclimatise to the north of the Mediterranean, in Provence, whereas sweet orange requires a warmer climate. 
Photo 2. Shadek, big green mandarina of the tropics and small strongly perfumed gombawa

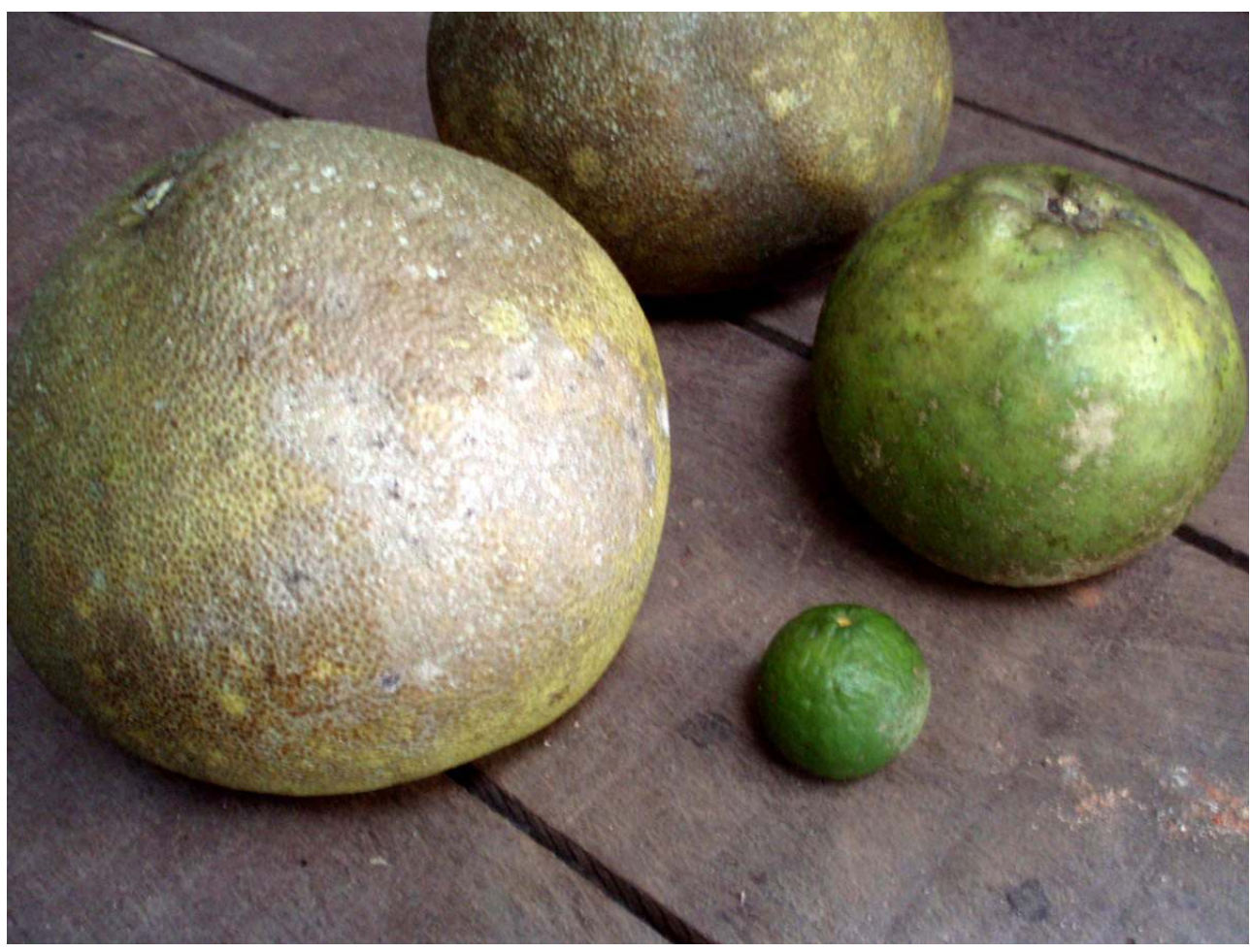

CLICHÉ F. AUBAILE, 2008

\section{Sweet orange, Citrus sinensis}

93 Sweet orange which is well-known, arrived in the Mediterranean very late. In the sixteenth century, it was brought from China by the Portuguese, who were the first to reopen the maritime road for a short time. It was therefore named portogal, bortogal in the Middle East.

Later on, in the eighteenth century, mandarins arrived and were accurately named Citrus deliciosus. In the nineteenth century, so did kumquat and hands of Buddha, two fruits created by the ingenuity of Chinese gardeners.

\section{Hollyhock, Althaea rosea}

95 The French rose trémière, a flower known in France as rose d'outremer (Robert 1979) in 1500. It originated in China and was diffused through the silk roads, but to date we ignore how. It seems to be well acclimatised in Central Asia : the author saw it on the roadsides of North Uzbekistan, Kazakhstan and Kyrgyzstan. Unknown to Andalusian botanists, it probably arrived in the Western Mediterranean at the end of the Middle Ages : the flower with three different coloured varieties - white, red and black - was very often depicted in late medieval European art around the end of the $15^{\text {th }}$ century (Sillasoo $2006: 65-66$ ). For instance, guli khaïra, its Persian name, is one of the most depicted on Persian miniatures with white and red flower varieties (Vullers $1855: 770$ et 1014) ${ }^{27}$. Andres de Laguna ( $\dagger$ 1560), the great Spanish scholar of the Renaissance, described it (Font Quer 1985 : 407). 


\section{Weeping willow ${ }^{28}$, Salix babylonica}

96 Weeping willow is native to China. Though the Mediterranean regions know many species of Salix, weeping willow was introduced very late in Europe from China, at the end of the $17^{\text {th }}$ century - in England in 1692 precisely and then in France ${ }^{29}$. There is little information about the tree's introduction in the Near East and by what paths. Rauwolf, who travelled there in 1573-1576, though he saw many "curious" willows, never described the weeping willow. Nowadays, the tree is grown in many humid places of the Near East, Turkey, Lebanon, Syria, Jordan, Israel, Palestine, etc., and in the Western Mediterranean. In Egypt, it is called safsaf el-mustahî (Bocthor 1848). Its bark is rich in salicin, has analgesic, antipyretic, antirheumatic properties, and is part of the components of aspirin (Encyclopaedia Britannica).

\section{Mediterranean plants introduced in China after Greco- Roman times}

\section{Henna, Lawsonia inermis}

Henna is native to Southwest Asia. It was traded along the sea route to China ${ }^{30}$. The name henna is of Indo-Aryan origin (Fig. 2).

Figure 2. Map of diffusion of the henna in time and space

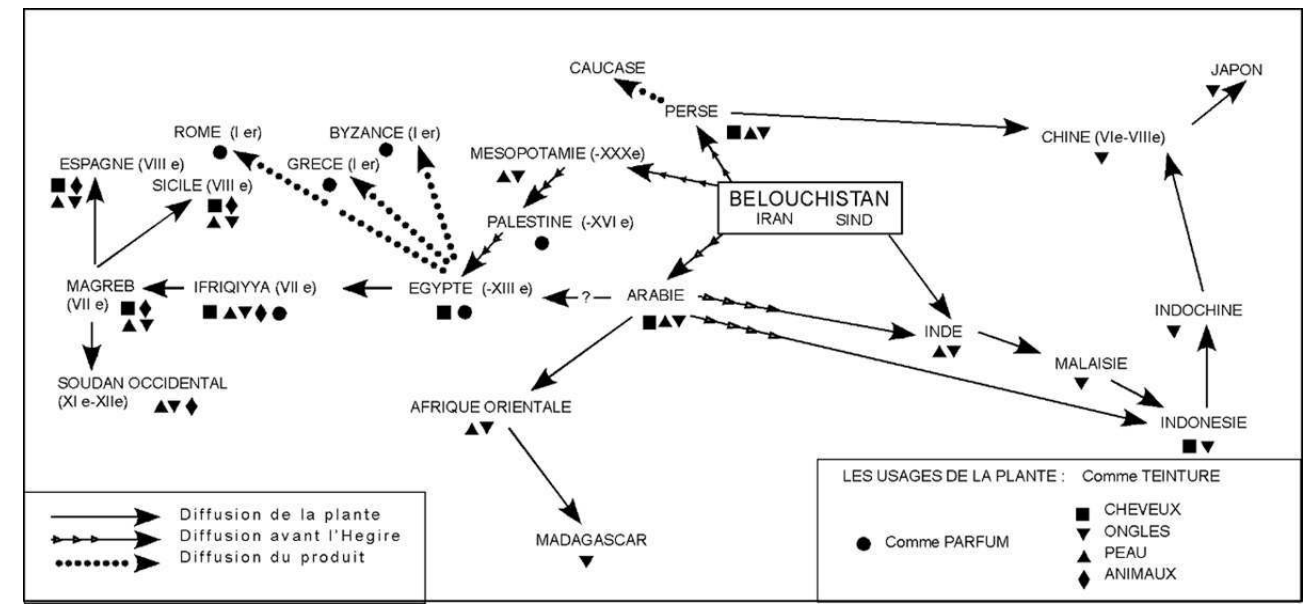

(AUbaile-sallenave, $1982:$ 130)

It was present in the Antiquity of the Middle East and Egypt in two forms : perfume that comes from the flowers and red dye that comes from the leaves. The mummy of Ramses II, like many others of that time, had its hair, feet and hands dyed with pouker, the Egyptian name for henna introduced in Ramesside times (Loret 1892: 80). The Hebrews exalted the aroma of the flower in the Song $(1,14 ; 4,12-14)$, a marriage song, but they never used it as a tint. On the contrary, the dye was well-known in Greek and Roman Antiquity.

Since the seventh century, Islamic societies have used it as a tint, especially in marriage rituals. The Moslems, traders and colonisers, played a major role in diffusing the plant with its magical and religious purposes - it was cherished by Muhammad and rich in 
baraka - from Maghreb to China, everywhere they went, in the Western Mediterranean, North Africa, Spain, Southern Italy and Sicily, and in Southeast Asia, Malaysia, Indonesia, Indochina, South China, and also in the sub-Saharan region and tropical North Africa. When the plant could not bloom and died every winter, such as in Andalusia, seeds were brought annually from Ascalon, in Palestine. In Spain, henna gave its name to Ligustrum vulgare : aleña. In India and probably Southeast Asia, people knew the ancient use of hand dying before the arrival of henna; there, henna competed with indigenous dye plants but, as a valuable tint, it was widely introduced and even entered the Chinese, Vietnamese and Indian pharmacopoeia (Aubaile-Sallenave 1982).

\section{Narcissus tazetta, Narcissus spp.}

Narcissus tazetta is native to the Eastern Mediterranean, was introduced in China from Anatolia probably through the silk roads. The famous account of traveller Tuan Ch'engShih from Tang times (618-907) spoke of narcissus naming it nai-gi, probably from the Persian term nârgis - «a Roman plant »-, but what it described was : a pink flower and orange heart are not a narcissus (Schafer 1963: 127). Nevertheless, it was much appreciated in the time of the Song dynasty (960-1279). Poets sang it, painters painted and drew it, and potters made precious goblets to grow it in. It is now naturalised in Iran, China, Japan and Vietnam. The forced cultivation of bulbs provides flowers in winter. It thus became the traditional New Year flower in China, Vietnam and also in Iran.

It is one of the favourite flowers of the Chinese. Its fragrance symbolises the purity of heart and soul, its straight and narrow leaves represent integrity, and finally it bravely blooms in the cold. Zhangzhou, Southeast China, already the capital of narcissus, is now the cradle of the revival of typical Chinese narcissus carving art !

To Chinese exiles, narcissus represents a sacred flower of their country. In Hawaii, for New Year celebrations, the Chinese chamber of commerce has been organising a narcissus festival since 1950 to preserve and teach Chinese art and culture.

\section{Garden pea, Pisum sativum}

Garden pea is native to Southwest Asia, was grown in the seventh millennium $B C$ in the Fertile Crescent (Kieslev 1999: 51-55). It reached Greece via the Black Sea. The Latin and Germanic tribes got it from the Greeks. It was diffused to India first and then reached China around 1000 CE by way of the Himalayas and Tibet (Purseglove 1968: 311; Janick 2001).

\section{Date, Phoenix dactylifera}

Date was domesticated in Mesopotamia and Northwest India (Haudricourt \& Hédin 1943 : 29). It was already grown in Egypt in the predynastic Amratian cultural phase ca. 3800-3500 BC, in Upper Egypt (Vartavan \& Asensi Amorós 1997 : 193). Dates were known in Canton as a Persian product and, in Tang, were much appreciated for their crisp, sugary nature. The tree was imported from Persia to Canton in that time, and the fruit was named "Persian jujube" due to its resemblance to this Chinese fruit. By the ninth century, date palm was cultivated in the same region (Schafer $1977: 97,1963: 121-122$ ). 
The merchant Suleyman, who travelled there in the mid-ninth century, stated that it was uncommon; only a few were found in gardens (Reinaud 1988 (2) : 23).

\section{Fig, Ficus carica}

Fig is native to Western Asia, was very early cultivated in the Jordan valley, in the ninth millennium BC (Kislev et al. 2006 : 1373), and arrived in Egypt together with grape vine in the third millennium (Haudricourt \& Hédin 1943: 129). It is unknown when it was imported into China, but in the ninth century, the merchant Suleyman asserted that fig was among the many fruits eaten by the Chinese (of Southeast China) (Reinaud 1845 (2) : 2).

\section{Conclusion}

To illustrate our title, we can state that the main diffusion routes between the two large areas of the Far East and the Mediterranean regions went through Central Asia long before silk trade began with the Han dynasty, in the second century BC.

For half a century, archaeological discoveries in the numerous oases of Central Asia, many of which disappeared in the sands at the end of the Bronze Age, have revealed an active agricultural life in the Bronze Age between the fourth and second millennium BC. The oases formed a dense network and a broad political and cultural system that was linked with other advanced civilisations of that time - the Fertile Crescent of Mesopotamia, Egypt, the Indus region, China. These oases are the missing link explaining the antique movements between Eastern, Southern, and Western Asia. The domestication of the two-humped camel, Bactrian camel, in the $3^{\text {rd }}$ millennium BC, exactly corresponds to this long period and explains the many introductions between Eastern and Western Asia.

It explains the introductions in the Mediterranean regions some one or two thousand years BC : cock, native to hot Northwest Indochina, arrived from continental Northern China through a northern road and possibly also from the tropical Indus Valley; originating from Central Asia, horse and camel, and possibly many plants such as rose, sweet apple, pistachio, black mulberry, walnut, alliums, onion (Allium cepa) and garlic; and from tropical Southeast Asia, pomegranate, rice, pepper.

Introductions from Central Asia in Greco-Roman times included carp, pheasant, stone fruits such as peach and apricot, and root crops like carrot. From tropical Southeast Asia : buffalo, peacock, taro, citron, cucumber. During the period centred on the roads of Central Asia to the Far East, major plants were introduced such as grape vine, alfalfa, Persian clover and, originating from the Mediterranean, safflower and animals of major importance - donkey and mule.

107 During the Middle Ages and until today, the expansion of the Islamic Arabs plays a key part in the introduction of many plants : originating from the Far East through roads of Central Asia, white mulberry and, much later, sweet orange, hollyhock, weeping willow, tea; coming from continental Central Asia, rhubarb, sweet marjoram, basils. When they conquered Persia (633-642), the Arabs found spinach in Central Asia and, in the South, plants that had previously been imported from India: sugar cane, eggplant, jasmine, Seville orange, lemon. They borrowed them all with their Persian names. 
At the same time, Mediterranean plants were introduced in China, probably through the silk road: narcissus tazetta and garden pea. Yet, the Islamic Arabs and the Persians brought henna to their settlements in Southern China - Canton, Quanzhou and Yangzhou -, which is essential to their social and religious cultures, as well as date and fig - two basic fruits of their traditional food.

\section{BIBLIOGRAPHY}

Albright W. F. 1949 (rev. 1961) - The Archaeology of Palestine : From the Stone Age to Christianity. Hardmondsworth, Middlesex (England), Penguin, $271 \mathrm{p}$.

Al-Tabarî Abû Ja'far Muhammad Bin Jarîr [839-0923], Waines D. (Trad.) 1992 - Ta'rikh al-rusul waal-mulûk. The History of Al-Tabari, Vol 36, The revolt of the Zanj. Albany, State University of New York Press, $229 \mathrm{p}$.

Al-Tignarî Muhammad b. Mâlik [ca 480/1087], García Sánchez E. (edición e introducción) 2006 Kitâb zuhrat al-bustân wa-nuzhat al-adhân. Esplendor del jardín y recreo de las mentes. Madrid, Consejo Superior de Investigaciones Científicas, 572 p. (Coll. Fuentes arábico-hispanas 32).

André J. 1985 - Les noms de plantes dans la Rome antique. Paris, Les Belles Lettres, 332 p.

Aristophane [0445 ?-0386 ? BC], Poyard C. (Trad.) 1875 - Aristophane. Traduction nouvelle. Avec une introduction et des notes. Paris, Librairie Hachette, $523 \mathrm{p}$.

Aubaile-Sallenave F. 1982 - Les voyages du Henné. JATBA 29 : 123-178.

Aubaile-Sallenave F. 1984 - L'agriculture musulmane aux premiers temps de la conquête : apports et emprunts. JATBA $31: 245-256$.

Aubaile-Sallenave F. 1992 - Zanbô'a, un citrus mystérieux chez les Arabes médiévaux d'alAndalûs. In Sanchez García E. (Ed.), Ciencias de la Naturaleza en al-Andalus. Granada (Espagne), CSIC : 111-134.

Aubaile-Sallenave F. \& Haudricourt A. G. 1995 - Vin de pommes, pommé et cidre. Histoire d'une boisson. In Drettas G. \& Gutvirth J. (Ed.), Hommage à Jeanine Fribourg. Meridies 5 (19-20) : 465-506.

Aubaile-Sallenave F. 2005 - Le thé, un essai d'histoire de sa diffusion dans le monde musulman. In Marín M. \& Puente C. de la (Ed.), El banquete de las palabras : la alimentación de los textos árabes. Madrid, CSIC : 153-191.

Bahuchet S. 1992 - Dans la forêt d'Afrique Centrale. Les Pygmées Aka et Baka. Paris, SELAF, 425 p.

Balon E. K. 2004 - About the oldest domesticated among fishes. Journal of Fish Biology 65 (supplement A) : 1-27.

Beja-Pereira A., England P. R., Ferrand N., Jorda S., Bakhiet A. O., Abdalla M. A., Mashkour M., Jordana J., Taberlet P. \& Luikart G. 2004 - African Origins of the Domestic Donkey Science 304 (5678) : 1781

Bocthor E. [1828-1829 $1^{\text {ère }}$ ed.] 1882 - Dictionnaire français-arabe. Revu et augmenté par Armand-Pierre Caussin de Perceval. Paris, Firmin Didot père et fils, 867 p. 
Bois D. 1928 - Les plantes alimentaires chez tous les peuples et à travers les âges. Histoire, utilisation, culture. II. Phanérogammes fruitières. Paris, Éditions Paul Lechevalier, 637 p.

Boulnois L. [1963] 1986 - La route de la soie. Genève, Olizane, 350 p.

Boulnois L. 1994 - Chevaux célestes et salive de dragon. Transferts de culture matérielle sur les « routes de la soie » avant le xii ${ }^{\mathrm{e}}$ siècle. Celestial horses and spittle of dragon. Material culture transfers on the « silk roads » prior to the $12^{\text {th }}$ century. Diogène $167: 18-42$.

Bourdeau L. 1893 - Conquête du monde végétal. Paris, Félix Alcan, 374 p.

Bray F. 1986 - The Rice Economies. Technology and Development in Asian Societies. Oxford, Basil Blackwell, $254 \mathrm{p}$.

Bresciani E. 1985 - The persian occupation of Egypt. In Gershevitch I. (Ed.), The Cambridge history of Iran, volume 2 The Median and Achaemenian periods. Cambridge, Cambridge University Press : 502-528.

Bretschneider E. 1870 - On the Study and Value of Chinese Botanical Works, with Notes on the History of Plants and Geographical Botany from Chinese Sources. Foochow (Chine), Rozario, Marcal \& Co : 51 p.

Bretschneider E. 1888 - Mediaeval Researches from Eastern Asiatic Sources. London, Trübner \& Co 352 p., 2 vol.

Burkill I. H. 1935 - A dictionary of the economic products of the Malay Peninsula. 2 vol. London, Crown agents for the colonies, $2402 \mathrm{p}$.

Campbell Thompson R. 1949 - A dictionnary of Assyrian Botany. London, The British Academy, $405 \mathrm{p}$.

Camps G. 1996 - Dromadaire. Encyclopédie Berbère, XVII. Aix-en-Provence, Edisud : 2541-2546.

Cantù C. 1859-1862 - Histoire des Italiens. [Texte imprimé] / par César Cantù ; trad. sous les yeux de l'auteur par M. Armand Lacombe, sur la deuxième édition italienne. Paris, Firmin Didot frères, fils et $C^{\mathrm{e}}$, 12 volumes.

Casabonne O. 2003 - Buffles et zébus au Proche-Orient ancien. In Lebrun R. (Ed.), Hethitica XVI. Mélanges Neu. (Série : Bibliothèque des Cahiers de l'Institut de linguistique de Louvain). LouvainLa-Neuve, Peeters : $1-9$.

Chang K. C. (Ed.) 1977 - Food in Chinese culture. Anthropological and Historical Perspectives. London, New Haven, Yale University Press, 448 p.

Cicero [44 BC], Freyburger G. \& Scheid J. (Trad.) 1992 - De divinatione, ii 26. De la divination. Paris, Les Belles Lettres, $247 \mathrm{p}$.

Clavairolle F. M., Costa E., Doulcier M., Nougarède H., Ozil M. H., Piault D., Travier M. \& Wiénin 1993 - Les chemins de la soie. Itinéraires culturels en Cévennes, Bas-Languedoc, Vivarais. SaintHippolyte-du-Fort, Espace-écrits : 364 p.

Cockrill W.R. 1981 - The water buffalo : a review. British Veterinary Journal 137 (1) : 8-16.

Columelle [III s.], Nisard C. (Ed. et trad.) 1844 - De Re Rustica. Paris, Dubochet et Cie : 165-517.

Darby W. J., Ghalioungui P. \& Grivetti L. 1977 - Food : The Gift of Osiris. 2 vol. London, New York, San Francisco, Academic Press, 910 p.

Defrémery C. 1854 - CR de Francisque Michel 1852, Recherches sur le commerce., la fabrication et l'usage des étoffes de soie, d'or et d'argent, et autres tissus précieux en Occident, principalement en France, pendant le moyen âge. Paris, Imprimerie de Crapelet. Journal Asiatique (février) :

162-174. 
Dupré S. 1993 - Bestiaire de Cappadoce : terres cuites zoomorphes anatoliennes du Ile millénaire avant J.C. au Musée du Louvre. Paris, Réunion des musées nationaux, 231 p.

Dureau de La Malle A. 1840 - Économie politique des Romains. Paris, Hachette, 2 vol. 454 p. et 512 p.

Dymock W. [1890] 1972 - Pharmacographia indica. Institute of Health and tibbi research, Karachi, Hamdard Foundation, $544 \mathrm{p}$.

Evans J., Wolfe E., Mun Y.G., Ri Y.J. \& Kim T.R., 2004 - Legumes for cropping systems in the Democratic Peoples Republic of Korea. New directions for a diverse planet : Proceedings of the 4th International Crop Science Congress. $12 \mathrm{p}$.

Font Quer, P. 1985 - Plantas medicinales, el Dioscorido renovado. Barcelona, Madrid, Edit. Labor, $1033 \mathrm{p}$.

Foust C. M. 1996 - Mysteries of Rhubarb : Chinese Medicinal Rhubarb through the Ages. HerbalGram The Journal of the American Botanical Council $36: 25-31$.

Guinea Lopez E. 1957 - Manzanas de España. Asturias. Madrid, Ministerio de Agricultura, Inst. Nac. de Investigaciones agronómicas.

Hambis L. 1964 - Papier. Dictionnaire archéologique des Techniques. Tome 2. Paris, Éditions de l'Accueil : 782-785.

Harris S.A., Robinson J.P. \& Juniper B.E. 2002 - Genetic clues to the origin of the apple. Trends in Genetics 18(8) : 426-430.

Haudricourt A.G. \& Hédin L. 1943 - L'homme et les plantes cultivées. NRF, Paris, Gallimard, Géographie humaine 19, $233 \mathrm{p}$.

Haudricourt A.G. 1987 - La technologie, science humaine. Recherches d'histoire et d'ethnologie des techniques. Paris, Éditions de la MSH, 343 p.

Hiebert F.T. 1994 - Origins of the Bronze Age Oasis Civilization in Central Asia. American School of Prehistoric Research, Bulletin 42. Cambridge, Mass., Peabody Museum of Archaeology and Ethnology, Harvard University. 240 p. (Review by Christopher Edens 1996, Bulletin of the American Schools of Oriental Research 301 : 91-94).

Hiebert-Howe 2001 - Archaeologists find Central Asia Civilization as old as Sumeria. Interview by Linda Moulton Howe, may 5, 2001, Philadelphia, Pennsylvania.

Ibn Al-Baytar [13 ${ }^{\text {th }}$ C.], Leclerc L. (Trad.) 1877-1883, 1987 - Traité des Simples. 3 vol. Fac-similé de l'édition de 1877-1883. Paris, IMA.

Istomin A.A. 1989 - Asses and Mules. In Dmitriev N.G. \& Ernst L.K. (Eds), Animal and genetic resources of the USSR. Rome, Food and Agriculture Organization of the United Nations, (FAO Animal production and Health Paper 65 series) : 408-424.

Janick J. 2001 - Asian Crops in North American. HortTechnology 11 : 510-513.

Juniper B.E. \& Mabberley D. 2006 - The story of the apple. Portland, Oregon, Timber Press, 240 p.

Kierstein G., Vallinoto M., Silva A., Schneider M.P., Iannuzzi L. \& Brenig B. 2004 - Analysis of mitochondrial D-loop region casts new light on domestic water buffalo (Bubalus bubalis) phylogeny. Molecular Phylogenetics and Evolution 30 (2) : 308-324.

Kislev M.E., Hartmann A. \& Bar-Josef O. 2006 - Early Domesticated Fig in the Jordan Valley. Science 312 (5778) : 1372-1374. 
Kislev M.E. 1999. - Agriculture in the Near East in the seventh millenium BC. In Anderson P.C. (Ed.), Prehistory of agriculture. New experimental and ethnographic approaches. Los Angeles, Institute of Archaeology, University of California : 51-55.

Laufer B. [1919] 1967 - Sino-iranica. Chinese contributions to the History of Civilization in Ancient Iran. Tai Pei (République de Chine), Ch'eng-Wen Publishing Company, $630 \mathrm{p}$.

Leclerc H. 1933 - Les fruits de France. Paris, Masson, 276 p.

Leclerc L. [1876], 1971 - Histoire de la médecine arabe. 2 vol. New York, Burt Franklin, 590 p.

Linschoten J.H. van 1610 - Histoire de la navigation de Iean Hugues de Linscot, Hollandois et de son voyage aux Indes orientales... à quoy sont adioustées quelques autres descriptions... du pays de Guinée, et autres costes d'Éthiopie... avec annotations de Bernard Paludanus. Amsterdam, Impr. H. Laurent, 283 p.

Loret V. 1892 (2 éd.) - La flore pharaonique d'après les documents hiéroglyphiques et les spécimens découverts dans les tombes. Paris, Leroux, $145 \mathrm{p}$.

Mabberley D.J. [1987] 1993 - The Plant-Book. A portable dictionary of higher plants. Cambridge Univ. Press. $707 \mathrm{p}$.

Masson V.M. 1964 - Sredniaia Aziia i Drevnii Vostok ("Central Asia and the Ancient Orient"). Review by Maurits Van Loon in Journal of Near Eastern Studies 30 (3) Jul. 1971 : 226-232.

McGovern P.E., Zhang J., Tang J., Zhang Z., Hall G.R., Moreau R.A., Nunez A., Butrym E.D., Richards M.P., Wang C.-S., Cheng G., Zhao Z. \& Wang C. 2004 - Fermented beverages of pre- and protohistoric China. PNAS (Proceedings of the National Academy of Sciences) 101(51) : 17594-17598.

Miller J.I. 1969 - The spice trade of the Roman Empire. Oxford, Clarendon Press, 294 p.

Moldenke H.N. 1952 - Plants of the Bible. Waltham, Mass. (USA), The Chronica Botanica Company, $328 \mathrm{p}$.

Moore K.M., Miller N.F., Hiébert F.T. \& Meadow R.H. 1994 - Agriculture and herding in the early oasis settlements of the Oxus Civilization. Antiquity 68(259) : 418-427.

Nachtsheim H. \& Stengel H. 1977 - Vom Wildtier zum Haustier. Berlin (West), Hamburg, Paul Parey Verlag, $156 \mathrm{p}$.

Newton C., Gonon T. \& Wuttmann M. 2005 - Un jardin d'oasis d'époque romaine à 'Ayn Manâwir (Kharga, Egypte). BIFAO 105 : 167-195.

Ohsson C. Baron d' 1852 - Histoire des Mongols depuis Tchinguiz-Khan jusqu'à Timour Bey ou Tamerlan. Amsterdam, Muller, 4 vol. ; in- $8^{\circ}$.

Olearius Adam Oelschlaeger (dit), Van Wicquefort Abraham (Trad.) 1727 - Voyages faits en Moscovie, Tartarie et Perse par le Sr Adam Olearius. Traduits et augmentés par le Sr de Wicquefort [Texte imprimé]. Amsterdam, M.C. Le Cène.

Outram A.K., Stear N.A., Bendrey R., Olsen S., Kasparov A., Zaibert V. Thorpe N. \& Evershed R.P. 2009 - The Earliest Horse Harnessing and Milking. Science 323, 5919 : 1332-1335.

Ovide [ $\mathrm{I}^{\mathrm{st}} \mathrm{AD}$ ], Lafaye G. (Ed. and trad.) 1930 - Les Métamorphoses. Paris, Les Belles Lettres. (Collection C.U.F., série latine).

Pelliot P. 1921 - Note sur les anciens itinéraires chinois dans l'Orient romain. Journal Asiatique $1: 139-145$.

Pline l'ancien [23-79] (Ed. et trad.) 1947-1995 - Histoire Naturelle. 30 volumes. Paris, Les Belles Lettres. (Collection des universités de France, Série latine). 
Plucknett D. L. 1976 - Edible Aroids : Alocasia, Colocasia, Cyrtosperma, and Xanthosoma (Araceae). In Simmonds N.W. (Ed.) Evolution of Crop Plants. London, Logman Group Limited : 10-12.

Purseglove J.W. 1968 - Tropical crops. Dicotyledons. 2 vol. London, Longman : 719 p. and 770 p.

Purseglove J.W. 1972 - Tropical crops : monocotyledons. 2 vol. London, Longman : 334 p. and 273 p.

Reinaud J.T. [1845] 1988 - Relation des voyages faits par les Arabes et les Persans dans l'Inde et à la Chine dans le ix $x^{e}$ siècle de l'ère chrétienne [Texte imprimé] : texte arabe imprimé en 1811 par les soins de feu Langlès / publié avec des corrections et des additions et accompagné d'une traduction française et d'éclaircissements par M. Reinaud. Tome 1, «Introduction et traduction »; Tome 2, « Notes de la traduction et texte arabe ». Osnabrück, O. Zeller, 2 vol. (Reprod. en fac-sim.)

Robert P. 1979 - Dictionnaire alphabétique et analogique de la langue française. Rédaction dirigée par A. Rey et J. Rey-Debove. Paris, Sté du nouveau Littré.

Rolland J.F. (Dir. de la réd.) 1968 - Histoire Universelle Illustrée, tome. 1, Naissance et rivalités des premiers empires. Lausanne, Éditions Rencontre, 191 p.

Ronan C.A. (Ed.) 1978 - The Shorter Science and Civilisation in China: 1 An Abridgement by Colin A. Ronan of Joseph Needham's Original Text. Cambridge, Cambridge University Press, 347 p.

Rossabi M. 1970 - The tea and horse trade with inner Asia during the Ming. Journal of Asian History $4: 136-168$

Rossi-Osmida G. (Ed.) 2002 - Margiana Gonur-depe Necropolis. 10 years of excavations by Ligabue Study and Research Centre. Padua, Il Punto Edizione, 218 p.

Saber A.S. 1998 - The Camel in Ancient Egypt. Proceedings of the third Annual Meeting for Animal Production Under Arid Conditions. The International Conference on Camel Production and Future Perspectives, vol. 1. United Arab Emirates, UAE University, 208-215.

Sauvaget J. (Ed.) 1948 - 'Ahbār -īn wa l-Hind [Texte imprimé] : Relation de la Chine et de l'Inde rédigée en 851 / Texte établi, traduit et commenté par Jean Sauvaget. Paris, Les Belles lettres, $80 \mathrm{p}$.

Savory T.H. 1970 - The Mule. Scientific American Offprint (december).

Schafer E.H. 1963 - The golden Peaches of Samarkand; A Study of T'ang Exotics. Berkeley \& Los Angeles, University of California Press, 399 p.

Schafer E.H. 1967 - The Vermilion Bird : T'ang Images of the South. Berkeley \& Los Angeles, University of California Press, 380 p.

Schafer E.H. 1968 - Hunting Parks and Animal Enclosures in Ancient China. Journal of the Economic and Social History of the Orient 11 (3) : 318-343.

Schafer E.H. 1977 - Food in chinese culture : T'ang. In Chang K. C. (Ed.), Food in Chinese culture. Anthropological and Historical Perspectives. New Haven, London, Yale University : 85-140.

Sillasoo Ü. 2006 - Medieval plant depictions as a source for archaeobotanical research. Vegetation History and Archaeobotany 16(1) : 61-70.

Stein A. 1916 - A Third Journey of Exploration in Central Asia, 1913-16. The Geographical Journal 48 (2) : 97-130.

Suetone [It AD], Henri Ailloud (Trad.) 1967 - Vie des douze Césars. Paris, Les Belles Lettres, 200 p. (Collection Classiques). 
Tang Loaëc R. \& Colombel P. 1983 - Chine, fresques du désert de Gobi. La route de la soie au Jardin des Plantes. Catalogue de l'exposition au Muséum national d'histoire naturelle. Paris, Éditions du CNRS, $130 \mathrm{p}$.

Theophrastus [370-285 BC], Hort A. (Ed. and trad.) [1916] 1968 - Enquiry into plants and minor works on odours and weather signs. 2 vol. London, Cambridge (Mass.), Harvard university press,

W. Heinemann, 475 p.and 499 p.

Tixier-Boichard M., Bed'hom B. \& Rognon X. 2011 - Chicken domestication : from archeology to genomics. Comptes Rendus Biologie, Académie des sciences, Paris. Elsevier Masson, 334 : 197-204.

Trombert E. 1997 - Des fleurs rouges en galette : Une plante tinctoriale dans la Chine ancienne : le carthame. Pancake-shaped red flowers : A dyeing plant in ancient China : Safflower. Journal asiatique 285 (2) : 509-547.

Uerpmann H.-P. \& Uerpmann M. 2002 - The Appearance of the Domestic Camel in South-east Arabia. The Journal of Oman Studies $12: 235-260$.

Vartavan C. de \& Asensi Amorós V. 1997 - Codex of Ancient Egyptian Plants Remains. Codex des restes végétaux de l'Egypte ancienne. London, Triade Exploration, $401 \mathrm{p}$.

Verdiev Z.K. \& Turabov T.M. 1989 - Buffaloes. In Dmitriev N.G. \& Ernst L.K. (Eds.), Animal and genetic resources of the USSR. Rome, Food and Agriculture Organization of the United Nations : 374-379. (FAO Animal production and Health Paper 65 series)

Vullers I.A. 1855 - Lexicon persico-latinum etymologicum. 2 vol. Impensis Adolphi Marci, Bonnae ad Rhenum, 965 p., 1566 p.

West B. \& Zhou B.X. 1988 - Did Chickens Go North? New Evidence for Domestication. Journal of Archaeological Science 15 : 515-533.

Yu Y.-S. 1977 - Food in Chinese culture : Han. In Chang K.C. (Ed.), Food in Chinese culture. Anthropological and Historical Perspectives. New Haven, London, Yale University Press : 53-84.

Yule H. \& Burnell A. C. [1903] 1984 - Hobson-Jobson : A Glossary of Colloquial Anglo-Indian Words and Phrases, and of Kindred Terms, Etymological, Historical, Geographical and Discursive. New Delhi, Munshiram Manoharlal, 1021 p.

Yule Col. Sir H. 1903. (Ed. and trad.) - The Book of Ser Marco Polo The Venetian Concerning Kingdoms and Marvels of the East. London, John Murray. 2 vol. in- $8^{\circ}, 462$ p. and 662 p.

Zeuner F. E. [1963] 1969 - A history of domesticated animals. London, Hutchinson, 560 p.

Zohary D. \& Hopf M. 2000 - Domestication of plants in the Old Word. The Origin and Spread of Cultivated Plants in West Asia, Europe and the Nile Valley. 3rd edition, Oxford, Oxford University Press, 316 p.

\section{NOTES}

1. He is the uncle of Red Baron Manfred von Richthofen, the famous World War 1 pilot.

2. These disorders that troubled China were experienced by the Persians and the Arabs who were established in Canton, in 758, and the Chinese Annals said that they took advantage thereof to loot the city and escape by sea (Reinaud 1845, 1 : CIX).

3. In referring to the Bible, Abraham had dromedaries (Gen. $12: 16 ;$ Gen. $24: 10,19$ ) and he lived, as scholars established, around $2000 \mathrm{BC}$. Thus, some consider domestication to be much earlier than stated in archaeology results. 
4. The first mention of dromedary was in $46 \mathrm{BC}$, when Caesar captured 22 dromedaries belonging to Juba I after the victory of Zita (Camps $1996: 2544)$.

5. Haudricourt, oral communication (Feb. 1994) and Juniper \& Mabberley (2006: 33). See Alma Ata, 'father of the apple', the name of the capital of Mongolia.

6. For that 'history', see Aubaile-Sallenave 1995 : 471-472, 475

7. A clone is a collection of plants descendant of a common ancestor and it is a known fact that asexual multiplication produces identical individuals; yet, external factors (e.g. insect bites transmit viruses) may potentially change this variety through the accumulation of viruses.

8. The Spanish proverb "manzano dura lo que su amo» (the apple tree lasts the lifetime of its master) clearly means that the master planted it when he was young (Guinea Lopez id.).

9. Theophrastus 3.6.2. Dioscorides claimed that it was introduced from Persia at the time of the first kings (Pliny 15, 87 in André 1985 : 34, 52).

10. This interesting piece of information was taken from the web, though the academic source could not be found.

11. Vavilov considers Central Asia as the primary centre of origin for onion and garlic.

12. Workers who built the Egyptian pyramids may have been fed with radishes and onions.

13. Roman coins of the first to the fifth centuries were found all along the sea routes from Aden to China, in Ceylon (Miller 1969 : 159, 177, 191, 208) and Indochina (id. p. 208).

14. Fish highly sought in ancient times. A large article is dedicated to it in the 19th century Larousse. From the Greek term skairos, it has vivid and changing colours and was common in Crete ; it is often called parrot-fish.

15. According to Juniper \& Mabberley (2006: 54), the Tien Shan area comprises wild species of temperate-zone fruit - plum, apricot, cherry - would apricot have migrated in the wild ? Or did it go back to wildness?

16. Transcaucasia comprises Armenia, the majority of Georgia and Azerbaijan. It has been the land of ancient kingdoms : of Media, Achaemenid, Parthian and Sassanid Empires.

17. Annals of Italy quoted by Dureau de la Malle, $2: 153$. The success of the Barbarian Invasions is in part due to their new locomotion technics, the horse harness for the Huns, and the evoluted carts for the Celtics. The italian stanga, the shaft, is a german name which came with the Lombards or the Ostrogots (Haudricourt $1987: 191$ ).

18. Plutarque (1619). This also appears in Aristophanes, Les Oiseaux (trad. Poyard $1875: 251,275$ ).

19. It may be compared with banana, also native to Oceania; though the latter was witnessed in Cosmas Indicopleustes [540-550 AD] (1958, I, 204, fig. 19) and Bahuchet (1992: 254-255) (Casson 1989). There is much unknown data for it : especially by what way and when it arrived on the East-African coast.

20. This oasis declined since $1700 \mathrm{BC}$ because of the change in direction of the river that supplied the town and crops.

21. Francisque Michel thought that the technique was introduced in Europe in the middle of the $6^{\text {th }}$ century (Defrémery $1854: 163$ ).

22. PEI KI SHI "Notes on an Embassy to the north" in Breitschneider 1888 (1: 31.

23. For this article, see my study "Le thé, un essai d'histoire de sa diffusion dans le monde musulman" (2005).

24. Commentator of the Erh-ya dictionary, in Bretschneider (1870:13).

25. We must also consider that of the Bibliothèque Nationale in Paris, as well as that of the Casanatense Library in Rome, not to mention those of Liège and Rouen. Elkhadem produced an edition and translation in 1990 (Louvains, Peeters).

26. Quoted in the $14^{\text {th }}$ century by the great pharmacologist Ibn al-Baytar (II), 1198. The accuracy of the Arab quotation is confirmed by Pliny : "Arabia produces sugar cane (saccharon), but the one that grows in India is more valued. It is a kind of honey that they harvest in the reeds, just as a white gum which cracks under the tooth" (XII-XVIII). 
27. According to Bahar, a North Indian scholar who wrote in 1768.

28. Linnaeus named it according to the legend of the weeping Jews, slaves in Babylon who would have sheltered under it.

29. In France, it was called "pleureur", in 1771 (Le Petit Robert).

30. See my extensive work "Les voyages du henné” (Aubaile-Sallenave 1982).

\section{ABSTRACTS}

Knowledge of the centres of origin of plants and animals has increasingly improved. However, it is much harder to identify the way through which plants and animals were distributed, by what roads and what means they arrived at one place or another, who brought them and who diffused them. Even for the most important and prestigious ones, many uncertainties persist. We cannot claim to resolve them, but we will present what is known to date about some major plants and animals, particularly the Asian ones that arrived in the Mediterranean region, and the other way, the ones that started in the Mediterranean and were diffused in the Far East.

L'on commence à bien connaître les centres d'origine des plantes et des animaux. Cependant, il est beaucoup plus difficile d'identifier les chemins par lesquels plantes et animaux se sont diffusés, les routes empruntées et par quels moyens ils sont arrivés dans un lieu ou un autre, qui les a apportés là ou les a diffusés. De nombreuses incertitudes subsistent encore pour les plus importants et les plus prestigieux. Nous ne prétendons pas résoudre toutes ces questions mais nous présenterons ce qui est connu aujourd'hui sur quelques plantes et animaux majeurs, tout particulièrement les asiatiques arrivés dans le bassin méditerranéen et, à l'inverse, ceux d'origine méditerranéenne et qui ont été diffusés en Extrême-Orient.

\section{INDEX}

Mots-clés: domestication, diffusion, animaux, plantes, Néolithique, Antiquité, Moyen Age

Keywords: domestication, diffusion, animals, plants, Neolithic, Antiquity, Middle Ages, Mediterranean region, Far East

Geographical index: Méditerranée, Extrême-Orient

\section{AUTHOR}

\section{FRANÇOISE AUBAILE}

UMR 7206 MNHN-CNRS-Université Paris Diderot

Éco-Anthropologie et Ethnobiologie

Muséum national d'histoire naturelle

Département Hommes, Natures, Sociétés

case postale 135, 57 rue Cuvier, 75005 Paris (France)

aubaile@mnhn.fr 